\title{
GIS system and livestock field survey as tools to manage the potential reducing of fuel load for fire prevention
}

Giovanni Pecora ${ }^{1}$, Mauro Musto ${ }^{2}$, Carmine D'adamo ${ }^{3}$, Francesco Adduci $^{4}$, Pierangelo Freschi ${ }^{5}$, Carlo Cosentino $^{6}$

\begin{tabular}{|c|c|}
\hline I N F O & A B S T R A C T \\
\hline Received: 23 Aug 2015 & \\
\hline Accepted: 23 Sept 2015 & This study would mark the potential role of grazing by Podolian cattle for reducing fuel \\
\hline Available on-line: 12 Oct 2015 & load of fire prevention and propagation. The interconnection of Geographic Information \\
\hline Responsible Editor: M. Herdon & $\begin{array}{l}\text { System (GIS) and livestock field survey allowed to monitor different grazing and no- } \\
\text { grazing areas in Basilicata region. }\end{array}$ \\
\hline Keywords: & Fifteen grazing areas were monitored for five years during the summer pasture, when the \\
\hline $\begin{array}{l}\text { GIS, livestock management, } \\
\text { biomass removal, fire } \\
\text { prevention }\end{array}$ & $\begin{array}{l}\text { Podolian cattle graze on green grazing areas. These areas were monitored by using GIS } \\
\text { system and GPS application. The potential impact of Podolian cattle was monitored for } \\
\text { the same time period. The cattle consistency allowed to calculate different parameters: } \\
\text { livestock unit, dry matter intake and stocking estimation of potential amount of dry matter } \\
\text { intake to understand the removal biomass in order to reduce the fuel load for fire } \\
\text { prevention. }\end{array}$ \\
\hline & $\begin{array}{l}\text { The spatial analysis (GIS) showed that there were only four grazing areas burned during } \\
\text { the time sampling, compared to the surrounding areas used as control (no-grazing area). } \\
\text { Therefore an efficient management of grazing by Podolian cattle could be an important } \\
\text { tool to prevent the fire propagation. }\end{array}$ \\
\hline
\end{tabular}

\section{Introduction}

Forest, shrubland biomass and grassland, which are formerly consumed by livestock and harvested by people for a variety of purposes, are increasing with the cease of traditional land use practices due to rural abandonment (Bland and Auclair, 1996; Moreira et al., 2001; Azevedo et al., 2010).

Livestock grazing influences factors that are related to both herbaceous and woody fuel characteristics: amount of herbaceous biomass live/dead fuel mix and continuity of fuel at a patch and landscape scale (Strand et al., 2014). Biomass removal by grazing animals is likely to be one of the most important factors for pasture ecosystem management (Leonard et al., 2010). This is particularly

\footnotetext{
${ }^{1}$ Giovanni Pecora

SAFE School of Agriculture, Forestry, Food and Environmental Sciences, University of Basilicata, Italy giov.pecora@gmail.com

2 Mauro Musto

SAFE School of Agriculture, Forestry, Food and Environmental Sciences, University of Basilicata, Italy mauro.musto@gmail.com

${ }^{3}$ Carmine D’Adamo

SAFE School of Agriculture, Forestry, Food and Environmental Sciences, University of Basilicata, Italy carminedadamo@hotmail.it

${ }^{4}$ Francesco Adduci

SAFE School of Agriculture, Forestry, Food and Environmental Sciences, University of Basilicata, Italy sodextra.77@gmail.com

${ }^{5}$ Pierangelo Freschi SAFE School of Agriculture, Forestry, Food and Environmental Sciences, University of Basilicata, Italy pierangelo.freschi@unibas.it

${ }^{6}$ Carlo Cosentino

SAFE School of Agriculture, Forestry, Food and Environmental Sciences, University of Basilicata, Italy carlo.cosentino@unibas.it
} 
true for autochthonous breed, since the animals are well adapted to the environment and highly capable to exploit the available resources, especially in marginal areas.

Podolian cattle is an autochthonous breed reared in South of Italy and adapted to the difficulty of the surrounding environment, such as the poor quality forages available in southern Italian pastures (Musto, 2003; Matassino and Ciani, 2009; Freschi et al., 2013;Musto et al., 2013). This breed is well appreciated not only for these capabilities, but also for meat and milk production. Podolian cattle is the most common breed kept in the hinterlands of Basilicata region (South of Italy), where the animals are generally reared under extensive or semi-extensive conditions (Freschi et al., 2015). This allows the animals to utilize different vegetation layers: forest layer $<3 \mathrm{~m}$, shrubland and grassland for all the year (Bianchetto et al., 2009). By prescribed grazing, Podolian cattle may play an important role for a sustainable and ecological management of the available resources, by reducing grass and shrub biomass (Pittroff et al., 2006; Fuhlendorf and Engle 2001). The husbandry of these cattle shows a number of positive environmental effects, such as increased climate stability, improved soil functionality, water quality and footprint and preservation from fires (Freschi el at., 2015).

In this context, Podolian cattle may be used to reduce fuel load, creating a firebreak area (Taylor 2006) (fuel-vegetation break). In fact, as suggested by Davison (1996), browsing and trampling by livestock can impact large fuels range (0.51-2.54 cm diameter).

In the present study, the occurrences of fire in different pasture of Basilicata region were monitored from 2010 to 2014. During the same period, the number of Podolian cattle kept on the same pastures areas was recorded to estimate livestock unit (LU) and their feed intake needs. These data were analyzed by means of Geographic Information System (GIS). This technique allows to locate and analyze objects and events that occur on the earth. There are various software technologies used based on GIS, as well as experiences within forestry sciences based on the management of digital territorial data, in order to process, store, analyze and integrate spatial data to produce information for the government and management of the territory (Masoni et al., 2005). Among the different GIS techniques, grid sampling is useful in survey planning. In this study case, the grid sampling was used to detect and record the fire occurrence in grazing and no-grazing areas, and the potential effect of grazing by Podolian cattle.

\section{Materials and methods}

\subsection{Study site}

The study site is Basilicata region (Figure 1), between $40^{\circ} 30^{\prime} 00^{\prime \prime} \mathrm{N}$ latitude and $16^{\circ} 30^{\prime} 00^{\prime \prime} \mathrm{E}$ longitude. The elevation ranges from 0 to $2248 \mathrm{~m}$ above sea level. Basilicata receives an average of $799 \mathrm{~mm}$ of rainfall per year. The region is characterized by different forest type: deciduous oaks (Quercus cerris L., Quercus Pubescens Willd.), beech forests (Fagus Sylvatica L.), Mediterranean shrubland and other minor species. with an area of 355.409 ha (Costantini et al., 2006).

A part of these forest areas are used by famers as summer pasture for Podolian cattle reared under extensive and semi-extensive system (Freschi et al., 2015). 


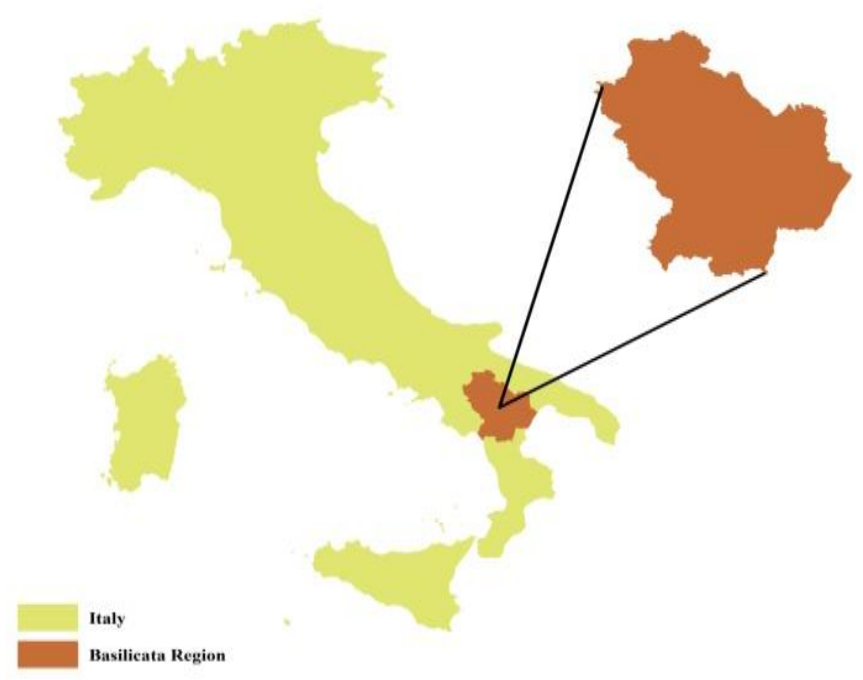

Figure 1. Basilicata Region localization

\subsection{Burned areas identification}

Fifteen grazing areas, located in 14 different municipalities of Basilicata (Table 2), were chosen using the criterion that the only animals allowed to graze belonged to Podolian breed. These areas were drawn by using open source GIS software. In these areas, the occurrences of fire was monitored for 5 years (2010-2014). The burned areas were recorded by using GPS (Garmin Montana 60T), mapped and classified in two classes: wooded burned area (WBA) and no-wood burned area (NWBA), with the aid of Forest Rangers of Basilicata region government to reach the burned area. The grazing areas and burned areas were analyzed by GIS technique. The extension (ha) of fire damage was measured within and in the surroundings of each grazing areas (no-grazing area) by overlay.

\subsection{Livestock production systems and pasture utilization of Podolian cattle}

Data (consistency and live weight) on Podolian cattle kept on each grazing area (Figure 2) were obtained in personal interviews with 15 farm operators. The number of animals was used to calculate the number of Livestock Unit, which, according to the European official regulation (Commission Regulation - EC n. 1200/2009), it is defined as follows: 0,0 LU for calves younger than 6 months, 0,6 LU for cattle between 6 months and 2 years, and 1,0 LU for cattle older than 2 years. The Stocking Density (SD) for each area was calculate by dividing the number of LU of each area by the extension (ha) of the same area.

The potential feed intake of Podolian cattle in each area was estimated according to Grenet et al. (1987). Grenet stated that dry matter intake for adult cattle is $14 \mathrm{~g} \mathrm{DM} / \mathrm{kg} \mathrm{LW} \mathrm{(DM} \mathrm{dry} \mathrm{matter,} \mathrm{LW}$ live weight). While the live average weight $(605 \mathrm{~kg})$ was estimated analyzing the weight data reported on farm registers.

The removal of potential biomass by Podolian cattle was estimated by multiplying the feed intake calculated in each area for 120, which is the period (summer season) characterized by highest incidence of fire, as well as the peak of the dry and hot temperatures combined with the lowest rainfall. 


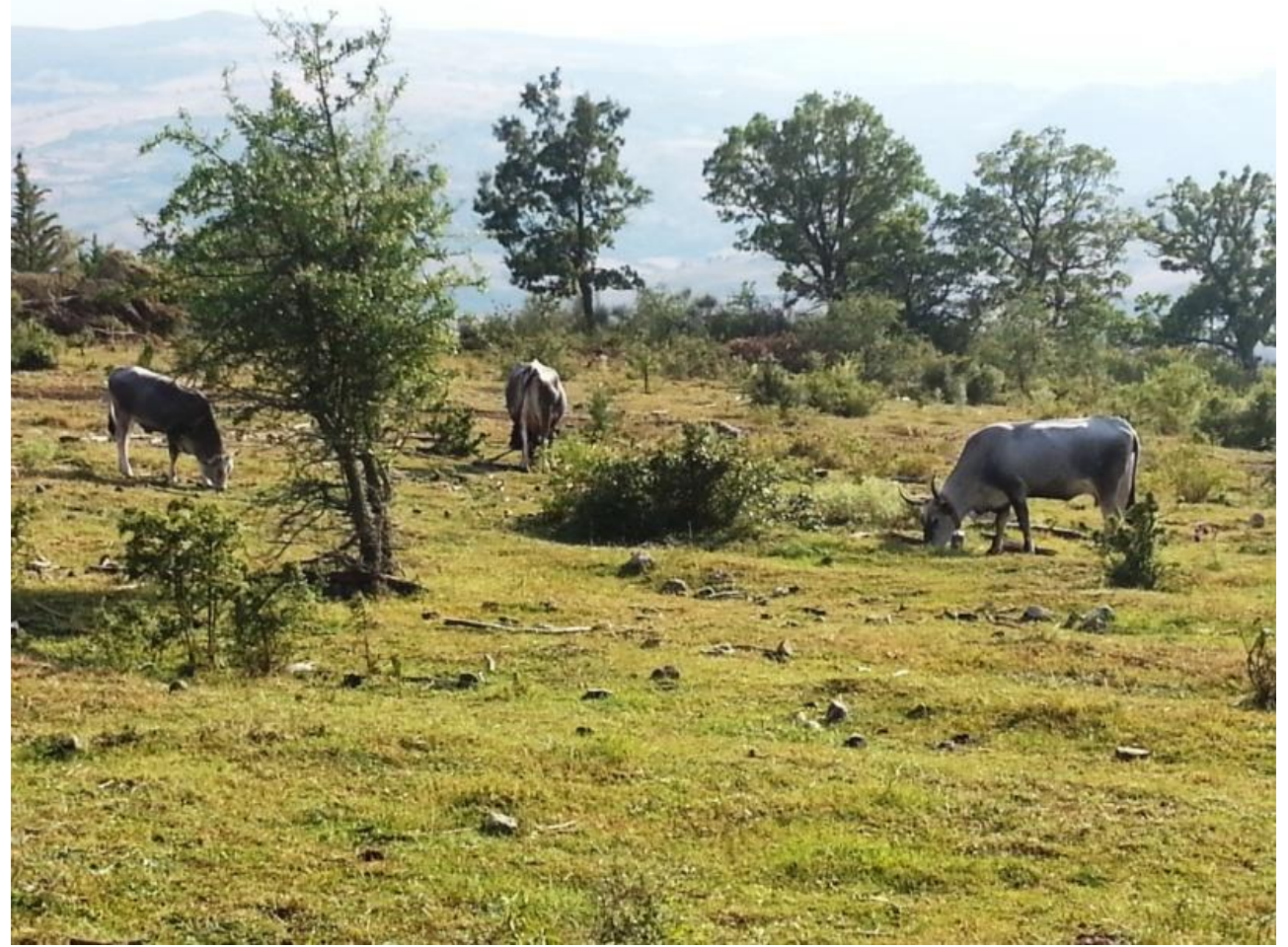

Figure 2. Podolian cattle during summer grazing

\subsection{Sampling method}

A grid $100 \mathrm{~m} \times 100 \mathrm{~m}(1 \mathrm{ha})$ was constructed (Fishnet tool) and overlaid on the grazing area to identify and record the fire frequency from the fire map. The grids were used as basic sampling unit to detect the fire frequencies, recording the presence/absence (1/0). This grid was also used for surrounding grazing areas, and a buffer area of $300 \mathrm{~m} \mathrm{(3} \mathrm{ha)} \mathrm{was} \mathrm{created} \mathrm{to} \mathrm{quantify} \mathrm{the} \mathrm{fire} \mathrm{presence}$ inside of no-grazing areas. Within each buffer area, no livestock were found during the monitoring time.

\section{Results and Discussions}

\subsection{Fire frequency}

The results from GIS analysis showed that only 4 areas (Area 1, 8, 12 and 15) were affected by fire (Table 1 and Figure 3, 4 and 5). In the Area 1 (Abriola/Pignola municipalities), the burned area had an extension of 120 ha in 2011, and 3,35 ha in 2012. In particular, in the grazing area (2011), 25 ha of WBA and 24 ha of NWBA were recorded, with a percentage incidence on the total grazing area of $4,7 \%$ and $4,4 \%$, respectively. In the no-grazing area, there were 35 ha of WBA and 41 ha of NWBA, with a percentage incidence on the total no-grazing area (buffer area) 7,5\% and $8,8 \%$, respectively. Moreover, in the 2012, 3,35 ha of NWBA were recorded in the grazing area $(0,6 \%$ of grazing area). In the Area 8 (Ferrandina municipality), in 2012, there were only 5 ha of WBA in the grazing area $(1,5 \%$ of total area). In the same year, in the Area 12 (Pescopagano municipality), the burned area had an extension of 2 ha of NWBA ( $0,3 \%$ of total of no-grazing area). During 2011, in the Area 15, there were 1 ha of WBA $(0,1 \%$ of total grazing area), 7 ha of WBA and 3,5 of NWBA $(1,8$ and $0,9 \%$ of total of no-grazing area, respectively). Figures 3, 4 and 5 show the different conditions for all grazing areas that are a support for the spatial analysis reported in the table 1 and 2.

These results show that in the grazing areas, the incidence of fire propagation was very low. The potential effect of removal biomass by Podolian cattle may be useful as a tool to prevent the fire propagation In fact, these breed showed, during the time, a number of positive environmental effects, such as increased climate stability, improved soil functionality, water quality and footprint and preservation from fires (Freschi et al., 2015). 
Table 1. GIS spatial analysis of fire monitoring in grazing areas

\begin{tabular}{|c|c|c|c|c|c|c|c|c|c|c|c|c|c|c|c|c|c|c|c|c|c|}
\hline \multirow[b]{3}{*}{$\begin{array}{c}\text { Grazing } \\
\text { area }\end{array}$} & \multirow[b]{3}{*}{$\begin{array}{c}\text { Superface } \\
\text { (ha) }\end{array}$} & \multicolumn{4}{|c|}{2010} & \multicolumn{4}{|c|}{2011} & \multicolumn{4}{|c|}{2012} & \multicolumn{4}{|c|}{2013} & \multicolumn{4}{|c|}{2014} \\
\hline & & \multicolumn{4}{|c|}{ Grazing area } & \multicolumn{4}{|c|}{ Grazing area } & \multicolumn{4}{|c|}{ Grazing area } & \multicolumn{4}{|c|}{ Grazing area } & \multicolumn{4}{|c|}{ Grazing area } \\
\hline & & WBA & $\%$ & NWBA & $\%$ & WBA & $\%$ & NWBA & $\%$ & WBA & $\%$ & NWBA & $\%$ & WBA & $\%$ & NWBA & $\%$ & WBA & $\%$ & NWBA & $\%$ \\
\hline 1 & 539 & 0 & 0 & 0 & 0 & 25 & 4,7 & 24 & 4,4 & 0 & 0 & 3,35 & 0,6 & 0 & 0 & 0 & 0 & 0 & 0 & 0 & 0 \\
\hline 2 & 267 & 0 & 0 & 0 & 0 & 0 & 0 & 0 & 0 & 0 & 0 & 0 & 0 & 0 & 0 & 0 & 0 & 0 & 0 & 0 & 0 \\
\hline 3 & 292 & 0 & 0 & 0 & 0 & 0 & 0 & 0 & 0 & 0 & 0 & 0 & 0 & 0 & 0 & 0 & 0 & 0 & 0 & 0 & 0 \\
\hline 4 & 290 & 0 & 0 & 0 & 0 & 0 & 0 & 0 & 0 & 0 & 0 & 0 & 0 & 0 & 0 & 0 & 0 & 0 & 0 & 0 & 0 \\
\hline 5 & 274 & 0 & 0 & 0 & 0 & 0 & 0 & 0 & 0 & 0 & 0 & 0 & 0 & 0 & 0 & 0 & 0 & 0 & 0 & 0 & 0 \\
\hline 6 & 100 & 0 & 0 & 0 & 0 & 0 & 0 & 0 & 0 & 0 & 0 & 0 & 0 & 0 & 0 & 0 & 0 & 0 & 0 & 0 & 0 \\
\hline 7 & 496 & 0 & 0 & 0 & 0 & 0 & 0 & 0 & 0 & 0 & 0 & 0 & 0 & 0 & 0 & 0 & 0 & 0 & 0 & 0 & 0 \\
\hline 8 & 276 & 0 & 0 & 0 & 0 & 0 & 0 & 0 & 0 & 0 & 0 & 0 & 0 & 0 & 0 & 0 & 0 & 0 & 0 & 0 & 0 \\
\hline 9 & 135 & 0 & 0 & 0 & 0 & 0 & 0 & 0 & 0 & 0 & 0 & 0 & 0 & 0 & 0 & 0 & 0 & 0 & 0 & 0 & 0 \\
\hline 10 & 490 & 0 & 0 & 0 & 0 & 0 & 0 & 0 & 0 & 0 & 0 & 0 & 0 & 0 & 0 & 0 & 0 & 0 & 0 & 0 & 0 \\
\hline 11 & 417 & 0 & 0 & 0 & 0 & 0 & 0 & 0 & 0 & 0 & 0 & 0 & 0 & 0 & 0 & 0 & 0 & 0 & 0 & 0 & 0 \\
\hline 12 & 680 & 0 & 0 & 0 & 0 & 0 & 0 & 0 & 0 & 0 & 0 & 0 & 0 & 0 & 0 & 0 & 0 & 0 & 0 & 0 & 0 \\
\hline 13 & 333 & 0 & 0 & 0 & 0 & 0 & 0 & 0 & 0 & 0 & 0 & 0 & 0 & 0 & 0 & 0 & 0 & 0 & 0 & 0 & 0 \\
\hline 14 & 281 & 0 & 0 & 0 & 0 & 0 & 0 & 0 & 0 & 0 & 0 & 0 & 0 & 0 & 0 & 0 & 0 & 0 & 0 & 0 & 0 \\
\hline 15 & 337 & 0 & 0 & 0 & 0 & 1 & $\mathbf{0 , 3}$ & 0 & 0 & 0 & 0 & 0 & 0 & 0 & 0 & 0 & 0 & 0 & 0 & 0 & 0 \\
\hline
\end{tabular}

Table 2. GIS spatial analysis of fire monitoring in no-grazing areas

\begin{tabular}{|c|c|c|c|c|c|c|c|c|c|c|c|c|c|c|c|c|c|c|c|c|c|}
\hline \multirow[b]{3}{*}{$\begin{array}{c}\text { Grazing } \\
\text { area }\end{array}$} & \multirow[b]{3}{*}{$\begin{array}{c}\text { Surface } \\
\text { (ha) }\end{array}$} & \multicolumn{4}{|c|}{2010} & \multicolumn{4}{|c|}{2011} & \multicolumn{4}{|c|}{2012} & \multicolumn{4}{|c|}{2013} & \multicolumn{4}{|c|}{2014} \\
\hline & & \multicolumn{4}{|c|}{ No-Grazing area } & \multicolumn{4}{|c|}{ No-Grazing area } & \multicolumn{4}{|c|}{ No-Grazing area } & \multicolumn{4}{|c|}{ No-Grazing area } & \multicolumn{4}{|c|}{ No-Grazing area } \\
\hline & & WBA & $\%$ & NWBA & $\%$ & WBA & $\%$ & NWBA & $\%$ & WBA & $\%$ & NWBA & $\%$ & WBA & $\%$ & NWBA & $\%$ & WBA & $\%$ & NWBA & $\%$ \\
\hline 1 & 463 & 0 & 0 & 0 & 0 & 35 & 7,5 & 41 & 8,8 & 0 & 0 & 0 & 0 & 0 & 0 & 0 & 0 & 0 & 0 & 0 & 0 \\
\hline 2 & 318 & 0 & 0 & 0 & 0 & 0 & 0 & 0 & 0 & 0 & 0 & 0 & 0 & 0 & 0 & 0 & 0 & 0 & 0 & 0 & 0 \\
\hline 3 & 254 & 0 & 0 & 0 & 0 & 0 & 0 & 0 & 0 & 0 & 0 & 0 & 0 & 0 & 0 & 0 & 0 & 0 & 0 & 0 & 0 \\
\hline 4 & 290 & 0 & 0 & 0 & 0 & 0 & 0 & 0 & 0 & 0 & 0 & 0 & 0 & 0 & 0 & 0 & 0 & 0 & 0 & 0 & 0 \\
\hline 5 & 276 & 0 & 0 & 0 & 0 & 0 & 0 & 0 & 0 & 0 & 0 & 0 & 0 & 0 & 0 & 0 & 0 & 0 & 0 & 0 & 0 \\
\hline 6 & 163 & 0 & 0 & 0 & 0 & 0 & 0 & 0 & 0 & 0 & 0 & 0 & 0 & 0 & 0 & 0 & 0 & 0 & 0 & 0 & 0 \\
\hline 7 & 332 & 0 & 0 & 0 & 0 & 0 & 0 & 0 & 0 & 0 & 0 & 0 & 0 & 0 & 0 & 0 & 0 & 0 & 0 & 0 & 0 \\
\hline 8 & 328 & 0 & 0 & 0 & 0 & 0 & 0 & 0 & 0 & 5 & 1,5 & 0 & 0 & 0 & 0 & 0 & 0 & 0 & 0 & 0 & 0 \\
\hline 9 & 171 & 0 & 0 & 0 & 0 & 0 & 0 & 0 & 0 & 0 & 0 & 0 & 0 & 0 & 0 & 0 & 0 & 0 & 0 & 0 & 0 \\
\hline 10 & 532 & 0 & 0 & 0 & 0 & 0 & 0 & 0 & 0 & 0 & 0 & 0 & 0 & 0 & 0 & 0 & 0 & 0 & 0 & 0 & 0 \\
\hline 11 & 343 & 0 & 0 & 0 & 0 & 0 & 0 & 0 & 0 & 0 & 0 & 0 & 0 & 0 & 0 & 0 & 0 & 0 & 0 & 0 & 0 \\
\hline 12 & 758 & 0 & 0 & 0 & 0 & 0 & 0 & 0 & 0 & 0 & 0 & 2 & 0,3 & 0 & 0 & 0 & 0 & 0 & 0 & 0 & 0 \\
\hline 13 & 318 & 0 & 0 & 0 & 0 & 0 & 0 & 0 & 0 & 0 & 0 & 0 & 0 & 0 & 0 & 0 & 0 & 0 & 0 & 0 & 0 \\
\hline 14 & 277 & 0 & 0 & 0 & 0 & 0 & 0 & 0 & 0 & 0 & 0 & 0 & 0 & 0 & 0 & 0 & 0 & 0 & 0 & 0 & 0 \\
\hline 15 & 394 & 0 & 0 & 0 & 0 & 7 & 1,8 & 3,5 & 0,9 & 0 & 0 & 0 & 0 & 0 & 0 & 0 & 0 & 0 & 0 & 0 & 0 \\
\hline
\end{tabular}



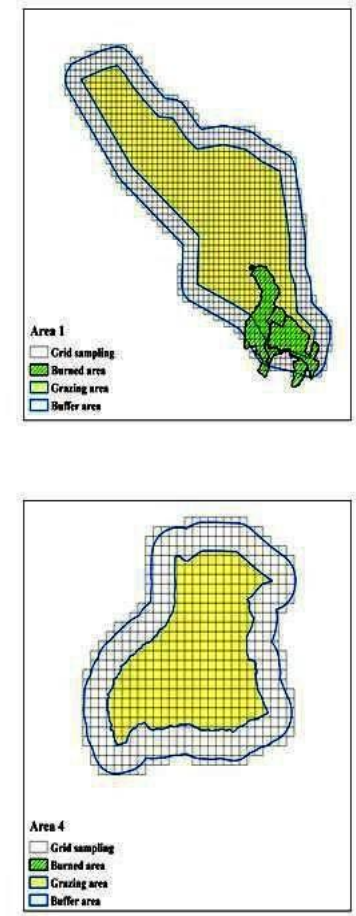
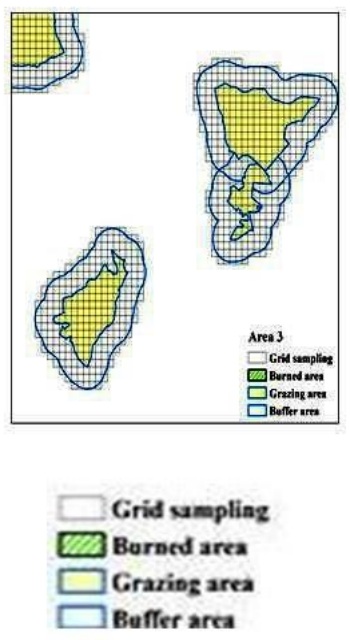
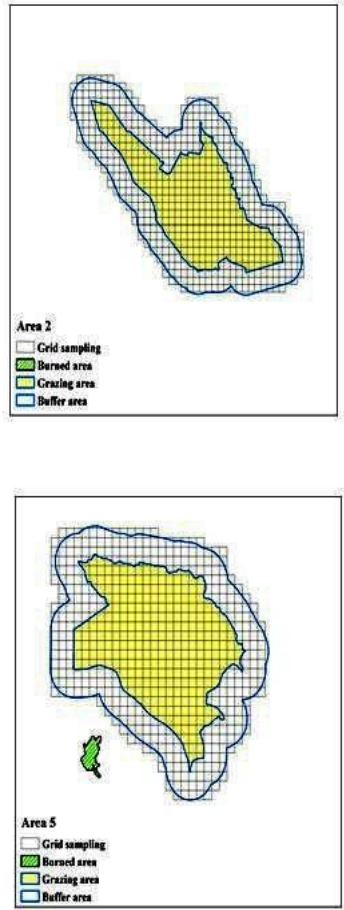

Figure 3. Grid sampling mapping, areas 1 to 5
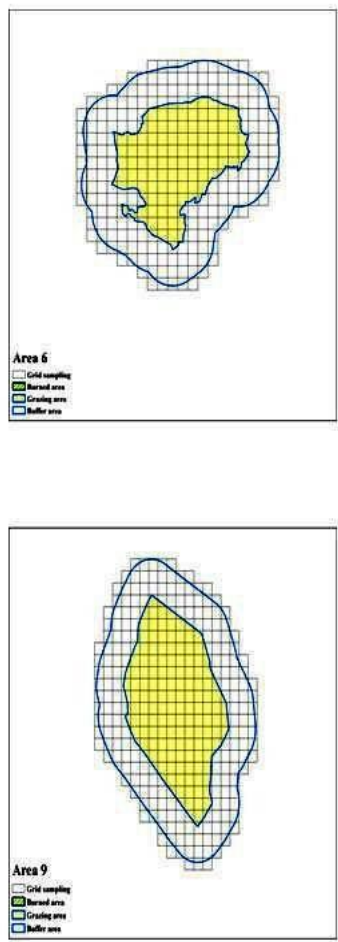

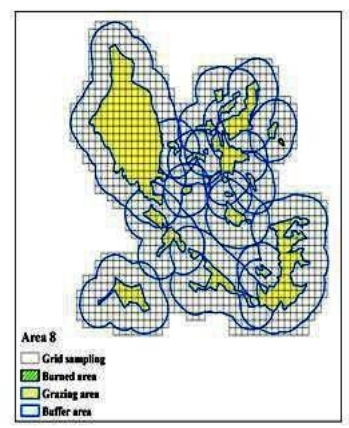

Area 7
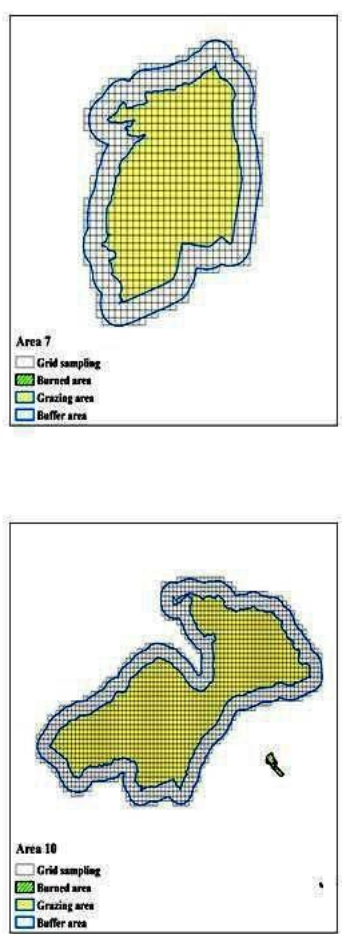

Figure 4. Grid sampling mapping, areas 6 to 10 

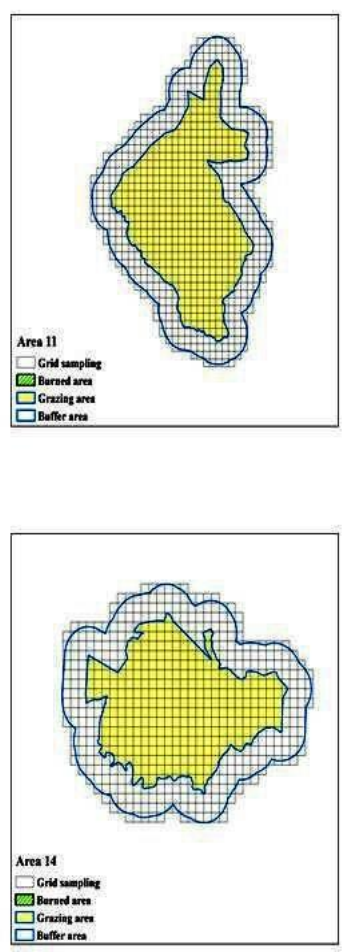

Figure 5. Grid sampling mapping. areas 11 to 15
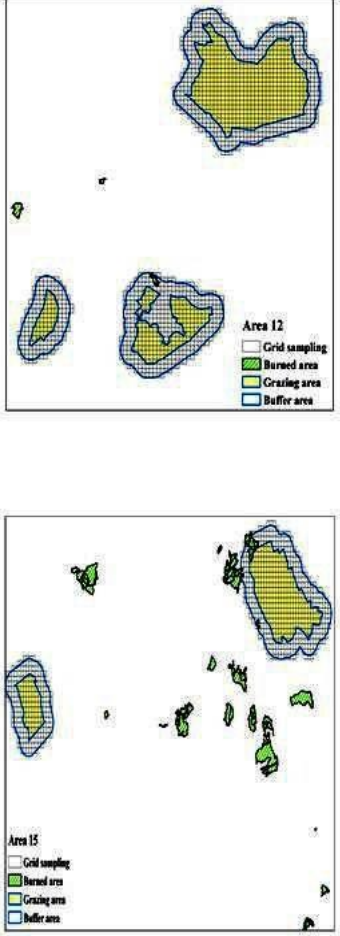

\subsection{Feed intake estimation of Podolian cattle}

In Table 3 and 4 are reported the main characteristics of Podolian cattle reared in the areas. Concerning stocking density (SD), in two grazing areas (Area 6 and 9) the parameter was more higher than in the other grazing areas. This was due to both small grazing surface and high consistency of Podolian cattle. SD resulted to be below the threshold values laid down in Nitrates Directive (91/676/CEE). However, it is recommended to keep a low livestock intensity in order to not create overgrazing, which in turn may lead to soil compaction by trampling, reduction of water infiltration, and increased surface run-off and erosion (Freschi et al., 2015)

Moreover, the value of dry matter intake for grazing time (DM) was the highest in 2013 due to substantial cattle turnover. This estimation allowed to understand how the Podolian cattle browsing may be an important tool to reduce the fuel in order to create a horizontal and/or vertical fuel break. In fact, the Podolian cattle may be an interesting tool for fuel reduction, just like goat (Lovreglio et al., 2014). Obviously, this goal should be achieved through appropriate measures, such as the use of metallic or electrified fence in order to maintain an appropriate stocking density, for browsing both the available foliage and twigs from all woody plants and all herbaceous vegetation.

Table 3. Feed intake estimation of Podolian cattle from 2010 to 2012

\begin{tabular}{|c|c|c|c|c|c|c|c|c|c|c|c|c|}
\hline \multicolumn{13}{|c|}{ Potential feed intake of Podolian cattle } \\
\hline \multirow{2}{*}{$\begin{array}{c}\text { Grazing } \\
\text { area }\end{array}$} & \multicolumn{4}{|c|}{2010} & \multicolumn{4}{|c|}{2011} & \multicolumn{4}{|c|}{2012} \\
\hline & $\mathrm{CO}^{1}$ & $\mathrm{LU}^{2}$ & $\begin{array}{l}\mathrm{DM}^{3} \\
(\mathrm{~kg})\end{array}$ & $\mathrm{SD}^{4}$ & $\mathrm{CO}^{1}$ & $\mathrm{LU}^{2}$ & $\begin{array}{l}\mathrm{DM}^{3} \\
(\mathrm{~kg})\end{array}$ & $\mathrm{SD}^{4}$ & $\mathrm{CO}^{1}$ & $\mathrm{LU}^{2}$ & $\begin{array}{l}\mathrm{DM}^{3} \\
(\mathrm{~kg})\end{array}$ & $\mathrm{SD}^{4}$ \\
\hline 1 & 187 & 140 & 141145 & 0,26 & 200 & 150 & 151227 & 0,28 & 167 & 125 & 126022 & 0,23 \\
\hline 2 & 107 & 80 & 80654 & 0,30 & 133 & 100 & 100818 & 0,37 & 153 & 115 & 115940 & 0,43 \\
\hline 3 & 253 & 190 & 191554 & 0,65 & 240 & 180 & 181472 & 0,62 & 247 & 185 & 186513 & 0,63 \\
\hline 4 & 247 & 185 & 186513 & 0,64 & 267 & 200 & 201635 & 0,69 & 260 & 195 & 196595 & 0,67 \\
\hline 5 & 140 & 105 & 105859 & 0,38 & 160 & 120 & 120981 & 0,44 & 120 & 90 & 90736 & 0,33 \\
\hline 6 & 140 & 105 & 105859 & 1,05 & 133 & 100 & 100818 & 1,00 & 153 & 115 & 115940 & 1,15 \\
\hline 7 & 113 & 85 & 85695 & 0,17 & 133 & 100 & 100818 & 0,20 & 167 & 125 & 126022 & 0,25 \\
\hline
\end{tabular}




\begin{tabular}{c|rrrr|rrrr|rrrr}
8 & 227 & 170 & 171390 & 0,62 & 240 & 180 & 181472 & 0,65 & 233 & 175 & 176431 & 0,63 \\
9 & 180 & 135 & 136104 & 1,00 & 200 & 150 & 151227 & 1,11 & 200 & 150 & 151227 & 1,11 \\
10 & 193 & 145 & 146186 & 0,30 & 187 & 140 & 141145 & 0,29 & 173 & 130 & 131063 & 0,27 \\
11 & 153 & 115 & 115940 & 0,28 & 160 & 120 & 120981 & 0,29 & 133 & 100 & 100818 & 0,24 \\
12 & 160 & 120 & 120981 & 0,18 & 173 & 130 & 131063 & 0,19 & 180 & 135 & 136104 & 0,20 \\
13 & 227 & 170 & 171390 & 0,51 & 240 & 180 & 181472 & 0,54 & 213 & 160 & 161308 & 0,48 \\
14 & 100 & 75 & 75613 & 0,27 & 107 & 80 & 80654 & 0,28 & 133 & 100 & 100818 & 0,36 \\
15 & 253 & 190 & 191554 & 0,56 & 240 & 180 & 181472 & 0,53 & 233 & 175 & 176431 & 0,52 \\
\hline
\end{tabular}

Table 4. Feed intake estimation of Podolian cattle from 2013 to 2014

\begin{tabular}{|c|c|c|c|c|c|c|c|c|}
\hline \multicolumn{9}{|c|}{ Potential feed intake of Podolian cattle } \\
\hline \multirow{2}{*}{$\begin{array}{c}\text { Grazing } \\
\text { area }\end{array}$} & \multicolumn{4}{|c|}{2013} & \multicolumn{4}{|c|}{2014} \\
\hline & $\mathrm{CO}^{1}$ & $\mathrm{LU}^{2}$ & $\mathrm{DM}^{3}(\mathrm{~kg})$ & $\mathrm{SD}^{4}$ & $\mathrm{CO}^{1}$ & $\mathrm{LU}^{2}$ & $\mathrm{DM}^{3}(\mathrm{~kg})$ & $\mathrm{SD}^{4}$ \\
\hline 1 & 200 & 150 & 151227 & 0,28 & 213 & 160 & 161308 & 0,3 \\
\hline 2 & 133 & 100 & 100818 & 0,37 & 133 & 100 & 100818 & 0,4 \\
\hline 3 & 240 & 180 & 181472 & 0,62 & 247 & 185 & 186513 & 0,6 \\
\hline 4 & 260 & 195 & 196595 & 0,67 & 253 & 190 & 191554 & 0,7 \\
\hline 5 & 160 & 120 & 120981 & 0,44 & 133 & 100 & 100818 & 0,4 \\
\hline 6 & 140 & 105 & 105859 & 1,05 & 133 & 100 & 100818 & 1,0 \\
\hline 7 & 133 & 100 & 100818 & 0,20 & 133 & 100 & 100818 & 0,2 \\
\hline 8 & 233 & 175 & 176431 & 0,63 & 233 & 175 & 176431 & 0,6 \\
\hline 9 & 207 & 155 & 156267 & 1,15 & 207 & 155 & 156267 & 1,1 \\
\hline 10 & 187 & 140 & 141145 & 0,29 & 173 & 130 & 131063 & 0,3 \\
\hline 11 & 160 & 120 & 120981 & 0,29 & 147 & 110 & 110899 & 0,3 \\
\hline 12 & 173 & 130 & 131063 & 0,19 & 173 & 130 & 131063 & 0,2 \\
\hline 13 & 240 & 180 & 181472 & 0,54 & 240 & 180 & 181472 & 0,5 \\
\hline 14 & 120 & 90 & 90736 & 0,32 & 107 & 80 & 80654 & 0,3 \\
\hline 15 & 240 & 180 & 181472 & 0,53 & 227 & 170 & 171390 & 0,5 \\
\hline Total & 2827 & 2120 & 2137335 & & 2753 & 2065 & 2081886 & \\
\hline
\end{tabular}

\section{Conclusions}

The GIS spatial analysis could be a tool for the improvement and development of "fireman profession". In fact, the application of these advanced software systems (GIS tools) may optimize the State Forestry Corps management interventions.

Concerning grazing, the prescribed grazing with Podolian cattle can reduce the fuel load of shrublands, grassland in the short term by partially reducing woody fuels. Moreover, livestock grazing may reduce fire ignition potential and spread by removing live and dead herbaceous vegetation and accelerating litter decay through trampling. However, the stocking density should not excessive in order to manage the pastureland and to reduce the fire propagation. 
Grazing can increase the propensity for fire to spread because the herbivores selectively remove green biomass and thereby increase the proportion dead to live biomass. Other limitations of grazing application for firefighting are directly related to weather and orographic conditions. In fact, under extreme burning conditions, (low fuel moisture and relative humidity, high temperature, wind speed and slope conditions), wildland fires are driven by weather conditions rather than by fuel characteristics and the positive effect of grazing on fire propagation may be nullified.

For these reasons, the relationship between GIS system and field livestock survey maybe useful for improving fire protection in Mediterranean areas like those of Basilicata region.

\section{Acknowledgment}

The research was conducted within the project "La Zoocosmesi per le imprese e l'innovazione di prodotto" financed by the Programma Operativo FSE Basilicata 2007-2013, Asse IV Capitale Umano.

We would like to thank Corpo Forestale dello Stato of Basilicata region, for the basic data of fire considered in this paper.

\section{References}

Azevedo, JC., C. Moreira Castro and JP. Loureiro C. 2010. Agriculture abandonment. land-use change and fire hazard in mountain landscapes in northeastern Portugal. In Landscape ecology in forest management and conservation -Challenges and solutions for global change (Li C. Lafortezza R. Chen J. eds). Springer. pp: 329 351., doi: 10.1007/978-3-642-12754-0_14

Bianchetto. E., G. Argenti and F. Ferretti. 2009. Proposta per una metodologia speditiva di stima del carico animale mantenibile da formazioni forestali nell'ambito della pianificazione territoriale - Forest@ 6: 129-136 2009., doi: 10.3832/efor0575-006

Bland, F. and D. Auclair 1996. Silvopastoral aspects of Mediterranean forest management. In: Western European silvopastoral systems. Étienne M. eds. INRA. pp: 125-141

Costantini, G., A. Bellotti. G. Mancino, M. Borghetti and A. Ferrara. 2006. Carta forestale della Basilicata Atlante. INEA - Regione Basilicata. Potenza. pp. 99. [ISBN 88-8145-062-3]

Davison, J. 1996. Livestock grazing in wildland fuel management programs. Rangelands. 18(6). 242-245

Freschi, P., M. Musto, R. Paolino and C. Cosentino.2015. Grazing and Biodiversity Conservation: Highlights on a Natura 2000 Network Site. The Sustainability of Agro-Food and Natural Resource Systems in the Mediterranean Basin. Springer, doi: 10.1007/978-3-319-16357-4_18

Freschi, P., M. Musto, G. Potenza. 2013. L'allevamento nei siti di Rete Natura 2000 della Basilicata. Atti del Convegno "Natura 2000 in Basilicata: percorsi di contaminazione tra natura, scienza, arte e cultura dei luoghi". Aliano (Mt), Italy, 4-6 Aprile, 47-49. (In Italian)

Grenet, N., D. Mlcol, J. Billant, P. D'hour, J.M Giraud, D. Leconte, P.A. Parrassin and Pecatte J.R. 1987: Simplification du pâturage pour les troupeaux bovins allaitants et les bovins d'élevage. Fourrages. 111. 283-298.

Leonard, S., J. Kirkpatrick and J. Marsden-Smedley. 2010.Variation in the effects of vertebrate grazing on fire potential between grassland structural types. Journal of Applied Ecology 47. 876-883., doi: 10.1111/j.13652664.2010.01840.x

Lovreglio, R., O. Meddour-Sahar and V. Leone. 2014. Goat grazing as a wildfire prevention tool: a basic review. iForest - Biogeosciences and Forestry 7. 260-268., doi: 10.3832/ifor1112-007

Masoni. M., Dibari. C., Siddi. E. 2005. I Sistemi Informativi Territoriali. Provincia di Pisa. [online] URL: http://sit.provincia

Matassino. D. and F. Ciani. 2009. Origin and history on "Podolian" in Italy. On the tracks of Grey Podolian cattle. Italy, July 10th 2009 Proceedings.

Moreira, F. FC. Rego and PG, Ferreira. 2001. Temporal (1958-1995) pattern of change in a cultural landscape of northwestern Portugal: implications for fire occurrence. Landscape Ecology 16: 557-567.

Musto, M., S. De Maria, R. Paolino, G. Potenza, C. Cosentino, A. R. Rivelli, P. Freschi. 2013. L'attività di pascolamento nei Siti di Interesse Comunitario della Basilicata. Atti del Convegno "Natura 2000 in Basilicata: 
percorsi di contaminazione tra natura, scienza, arte e cultura dei luoghi”. Aliano (Mt), Italy, 4-6 Aprile, p.80. (In Italian)

Musto, M. 2003. Consumer concerns and podolian model potential .Large Animals Review. 9( 4): 17-20

Pittroff, W., N. Narvaez, R. Ingram, S. Barry, G. Nader Morgan and M. Doran. 2006. Prescribed herbivory for fire fuels management. In: Proceedings of the Symposium "Society for Range Management" (Barry S. Risberg D). San Jose (CA. USA). 23 June 2006. California-Pacific Section Society for Range Management. University of California Cooperative Extension. San Jose. CA. USA. pp. 2.

Strand, E. K., L. Karen Launchbaugh and F. Ryan Limb. 2014. Livestock grazing effects on fuel loads for wildland fire in sagebrush dominated ecosystems. 35-57. In Journal of Rangeland Applications. http://journals.lib.uidaho.edu/index..

Taylor, C.A. 2006. Targeted grazing to manage fire risk. In: "Targeted grazing: a natural approach to vegetation management and landscape enhancement" (Launchbaugh K ed). American Sheep Industry Association - ASI. Washington. DC. USA. pp. 108-114. [online] URL:

http://www.cnr.uidaho.edu/rx-grazing/Handbook/Chap ter_12_Targeted_Grazing.pdf 